Texas A\&M University-San Antonio

Digital Commons @ Texas A\&M University-San Antonio

Educational Leadership Faculty Publications College of Education and Human Development

7-17-2020

\title{
Care and Value-Creating Education Put into Action in Brazil: A Narrative Inquiry
}

Vicki G. Mokuria

Stephen F Austin State University

Diana Wandix-White

Texas A\&M University-San Antonio, dwhite@tamusa.edu

Follow this and additional works at: https://digitalcommons.tamusa.edu/edld_faculty

Part of the Education Commons

\section{Repository Citation}

Mokuria, Vicki G. and Wandix-White, Diana, "Care and Value-Creating Education Put into Action in Brazil: A Narrative Inquiry" (2020). Educational Leadership Faculty Publications. 3.

https://digitalcommons.tamusa.edu/edld_faculty/3

This Article is brought to you for free and open access by the College of Education and Human Development at Digital Commons @ Texas A\&M University-San Antonio. It has been accepted for inclusion in Educational Leadership Faculty Publications by an authorized administrator of Digital Commons @ Texas A\&M University-San Antonio. For more information, please contact deirdre.mcdonald@tamusa.edu. 
Volume 9, Issue SI (2020), pp. 14-32 Journal of Interdisciplinary Studies in Education ISSN: 2166-2681 Print/2690-0408 Online

\title{
Care and Value-Creating Education Put into Action in Brazil: A Narrative Inquiry
}

\author{
Vicki G. Mokuria \\ Stephen F. Austin State University, USA \\ Diana Wandix-White \\ Texas A\&M University-San Antonio, USA
}

\begin{abstract}
This narrative inquiry highlights the experiences of self-identified Soka educators in a PreK-12 th grade school in São Paulo, Brazil, as well as volunteers through a program called "Soka Education in Action." Through their narratives, the role of care in value-creating education is explored as a critical aspect of education that supports students' academic and personal growth and development, as well as educators' professional identity and selfactualization. This study clarifies the essential qualities of Soka educators as understood and articulated by practitioners in the field. The narratives shared by study participants illuminate Soka education as a catalyst that fosters global citizenship by encouraging students to recognize their roles as agents of societal change and instruments of social justice.
\end{abstract}

Keywords: Brazil, care, Soka education, teacher attributes

\section{INTRODUCTION}

Contemporary education around the world continues to be driven by standards-based high-stakes accountability systems that ensure that those who score the highest on exams will gain entrée into the best universities, which often increases a young person's chances of being "successful" in society. Such an approach can be competitive and demoralizing for those students who 
may not excel academically or who lack the cultural capital often required for the Euro-dominant and heteronormative views of societal "success" (Breinholt \& Jæger, 2020). Many educators seek fresh ideas to counter the persistent pressure bearing down on education from market-driven economic forces. One such educational philosophy that emerged in the $20^{\text {th }}$ century is called "Soka" educational philosophy. As ideas of Soka educational philosophy move westward into the schoolhouse from its Eastern origins in Japan, our current era is an ideal time to pause and explore the emergence of this approach to education in the context of Brazil, a country where these ideas have spread in Pre-kindergarten (PK) through $12^{\text {th }}$ grade settings.

This paper uses narrative inquiry as a method of research to engage with self-identified Soka, or "value-creating," educators in two contexts in Brazil: (a) at the PK-12 ${ }^{\text {th }}$ grade Brazil Soka School and (b) through Soka Education in Action (formerly known as The Makiguchi Project in Action), a network of volunteers who conduct professional development linked to Soka educational philosophy in Brazilian public schools. This value-creating approach to education is rooted in a culture of care that seeks to foster students to become global citizens who will act in the world as agents of social change in their local communities. A major focus of this paper lies in its aim to clarify the quintessential qualities of Soka educators, as understood and articulated by practitioners, using narrative inquiry as a methodology.

The research that comprises this paper was conducted by the first author in São Paulo, Brazil, in December 2018 through extensive interviews and visits with educators who self-identify as Soka educators. Some of the data was also collected during a previous research trip to Brazil in 2015. Since Brazil is the only country outside of Asia with a formal PK-12th grade Soka school, this research is especially important as educators around the globe are seeking ways to put the theoretical ideas about Soka educational philosophy into action. Since the Brazil Soka School has an International Baccalaureate (IB) component on the high school level, this study is particularly relevant because of the ways the educators bring together value creating ("Soka") education with critical thinking around global issues. A central component of Soka educational philosophy is students' lifelong happiness (Goulah, 2010; Ikeda, 2009). The role of care in Soka education will be explored as a critical aspect of education that supports students and educators to create value under any circumstance, along with how to support educators to expand their capacities to show care for their students.

\section{LITERATURE REVIEW}

The theoretical foundation of Soka educational philosophy is rooted in the ideas of the Japanese educator Tsunesaburo Makiguchi (1871-1944), considered the "father" of Soka, or "value-creating" education; his philosophy of education emerged from reflections on his pedagogy as a teacher in Japan 
prior to World War II. In his era, many scholars viewed Makiguchi as having "radical" ideas because his ideas about education were counter to the ultranationalistic views many educators in his time espoused. Makiguchi vehemently opposed the militaristic Japanese educational system while also seeking "to choose to be a change agent working within established structures" (Gebert \& Joffee, 2007, p. 70). A fellow teacher, Josei Toda, took Makiguchi as his mentor and learned about value-creating education from him (Goulah, 2010).

Daisaku Ikeda took the mantle of Soka educational ideas from Toda and crystallized them into a school system primarily situated in Asia, which, according to the Soka Gakuen Educational Foundation (2009), includes 6 Soka kindergartens, 3 Soka elementary schools and 3 Soka secondary schools; the only official PK-12 ${ }^{\text {th }}$ grade Soka school outside of Asia is in São Paulo, Brazil, which is at the center of this research. Ikeda (2006) succinctly shared his ideas about Soka educational philosophy in an address in 2005, explaining that knowledge alone cannot give rise to value. It is only when knowledge is guided by wisdom that value - defined by the father of Soka education, Tsunesaburo Makiguchi, as beauty, benefit, and goodness-is created. The font of wisdom is found in the following elements: an overarching sense of purpose, a powerful sense of responsibility and finally, the compassionate desire to contribute to the welfare of humankind (p. 173). Ikeda clarifies central aspects of Soka educational philosophy, emphasizing compassion and the importance of students developing a sense of purpose to improve life for all people.

In simplest terms, Ikeda's core ideas about Soka educational philosophy focus on:

- centering students' entire education on their lifelong happiness - both for themselves and others, so students develop the spirit to contribute to the well-being of all;

- focusing on curricular ideas towards developing students to become global citizens and recognizing the interconnectedness of all life by including these topics: (a) peace education; (b) human rights education; (c) environmental education; and (d) development education;

- emphasizing the importance of teachers developing meaningful and caring attitudes towards all students (Ikeda, 2010; Nagashima, 2012; Sharma, 2011).

The above ideas are pillars of Soka educational philosophy; the remainder of this paper focuses on attributes of self-identified Soka educators, including a brief history of Soka education and how it is applied today in Brazil in both formal and informal settings.

Value-creating, or Soka, pedagogy first developed by Makiguchi, is now seen as a "spirit of educating, an ethos, or conceptual foundation of 
education rather than defined methodology (Goulah \& Urbain, 2013, p. 309). The notion of creating value in education shifts the narrative about the "why"- the very purpose of education--and links education's purpose directly to a form of happiness that students generate from within themselves together with teachers, regardless of the time or circumstances. At the same time, the idea of students and teachers creating value is linked to their wellbeing and greater societal good. Ikeda (2009) emphasizes this point, noting that "our worth as a human being is determined by whether we live in a society solely for ourselves or strive to realize happiness for ourselves and others" ( $p$. 139). This point about Soka educational philosophy is critical. Ikeda, who is currently 92 years old and lives in Japan, persists in devoting his life to Soka educational philosophy and seeing it actualized, while also writing extensively on nuclear disarmament, peace, and essays that center on humanistic views of life and ways to apply these ideas to education and daily living (Garrison, Hickman \& Ikeda, 2014; Ikeda, 2001; Sherman, 2016).

It is important to address the term "soka" and its use, based on research conducted by other scholars and researchers. Goulah and Gebert (2009) write "any proactive engagement with one's environment that generates more beauty, gain, or good falls under the rubric of soka, or value creation" (p. 126), suggesting that the principles of soka can be applied in a wide range of areas beyond education - by asking ourselves how value is being created in any given situation. While this is true, the term "soka" would not necessarily be capitalized all the time as is used by educational scholars; the term "Soka" (capitalized) as an educational philosophy will be used throughout the paper to align with other scholars in the field.

To date, there is little published research on how Soka educational philosophy is directly applied in formal educational settings. Two key articles, however, include the following: 1) Silva (2000) studied Brazil's "Makiguchi Project in Action" (now called "Soka Education in Action"), and 2) Guajardo and Reiser (2016) conducted research on ways global citizenship education is applied in a higher education setting at the Soka University's Faculty of International Liberal Arts (FILA) in Japan. The research at the heart of this paper seeks to fill a gap in scholarly research on ways Soka educational philosophy are applied in both formal and informal settings in Brazil, while specifically using narrative inquiry to identify quintessential qualities of selfidentified Soka educators.

\section{NARRATIVE INQUIRY AS A METHODOLOGY TO STUDY SOKA EDUCATION}

In his work, "My Pedagogic Creed," John Dewey (1897) wrote: "education, therefore, is a process of living and not a preparation for future living” (p. 22). As Dewey's philosophical shift in education ushered in a fresh 
approach to education into Western consciousness, education scholars such as Eliot Eisner (1988) suggest we need to reconsider how we study education, saying "method influences how we think and what we are permitted to feel" (p. 19). Further, Eisner (1988) insists that educational researchers need to go "back to the schools, not to conduct commando raids, but to work with teachers as colleagues in a common quest and through such collaboration to rediscover the qualities, the complexities, and the richness of life in classrooms" (p. 19). These ideas, then, are at the heart of narrative inquiry: relational research and the centrality of teachers' voices and stories.

In essence, narrative inquiry - as a research methodology in education - emerged to support Deweyan notions of the very purpose of Western education - ideas that parallel those of Makiguchi. Narrative inquiry is a relational approach to educational research, in which the educators and researchers function together as collaborators; however, it is the stories of educators that are lifted up as the heart of the research. Their words and stories become the data that are honored, rather than critiqued and evaluated. A key component of narrative inquiry as a methodology is that researchers collaboratively engage "...in living, telling, retelling, and reliving stories" (Connelly \& Clandinin, 1990, p. 4). This methodological approach perfectly fits this research, which explores how self-identified Soka educators make meaning of their experiences and articulate what they believe to be the qualities essential for those who aspire to be Soka educators.

Soka educational philosophy is directly connected to the methodology of narrative inquiry, linked together by three important concepts, especially in relation to research of Soka education in Brazil: 1) teachers as curriculum makers (Clandinin \& Connelly, 1992; Craig \& Ross, 2008); 2) the term the "best loved self" (Clandinin, 2015; Craig, 2013; Schwab, 1954), and 3) ways that knowledge communities (Olson \& Craig, 2001) provide an important space for relational and dialogical knowing. In figure 1, the Venn diagram shows unique aspects of both Soka educational philosophy and narrative inquiry, and in the center, how they converge.

\section{Figure 1}

Venn diagram comparing Soka educational philosophy and narrative inquiry 


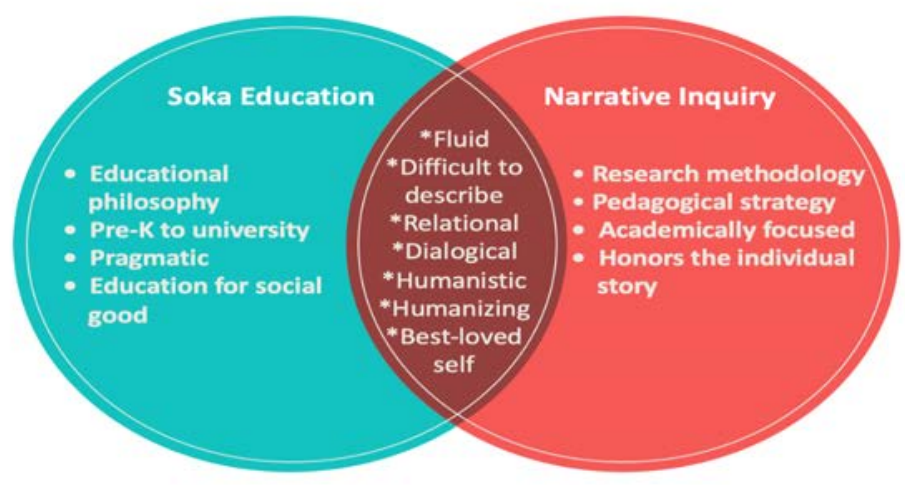

Based on this figure, it is clear that narrative inquiry is well-suited as a research tool when studying how Soka education is applied in various educational contexts.

\section{RESEARCH OVERVIEW}

This research in Brazil focused on two distinctive programs: 1) The Brazil Soka School, a private school, with a total of 422 students during the 2018-2019 school year and a staff of 52, which included 41 teachers and administrative staff members, and 2) the Soka Education in Action Program, which has a total of 48 teams and 336 volunteers in 20 cities throughout Brazil. These teams of volunteers reach out to local public schools and provide free professional development activities that are linked to principles of Soka educational philosophy once a month for eight months.

The research for this study, conducted in 2018, centered on identifying quintessential qualities of self-identified Soka educators. The data used for this research came from 10 self-identified Soka educators who work in disparate educational settings in Brazil: three of the volunteers were from a focus group who were active volunteer educators in the Soka Education in Action Program; one of the interviewees was the pioneering founder of the Makiguchi Project in Action (now called Soka Education in Action) and the founding principal of Brazil Soka School; and six of the interviewees were teachers at the Brazil Soka School in 2018, at the time of the research. The interviews occurred in São Paulo, Brazil, in December 2018, and pseudonyms are used throughout this paper to provide anonymity.

In addition to conducting interviews, the first author spent time as a participant observer in the Soka Education in Action program and attended two introductory sessions in public schools in São Paulo. At the Brazil Soka School, time was also spent interacting with students and staff during all 
shared meals/snack times, as well as during the staff's end-of-the-year all-day professional development activity, which provided opportunities for observations, interactions, and organic engagement.

\section{FINDINGS}

The woman who worked tirelessly to take responsibility for bringing Soka education to Brazil had a position as a supervisor at an adult literacy program in São Paulo in the 1970s; at that time, only literate adults could vote, so literacy programs developed to support people to learn to read so they could vote. The pseudonym used for this pioneer of Soka education in Brazil is "Delia." In her own words, this is how she described the situation that prompted her to take action:

This literacy program was done in 400 hours. They [the students] didn't have bathrooms, paper, coffee nothing...the facilities were filthy dirty and substandard. This one teacher wrote ' $A$,' ' $B$,' ' $C$ ' and repeatedly told the students to copy, copy, copy. I would watch this go on each evening. No one could stand it. It was terrible. Students worked hard, came to class exhausted, dirty, illiterate, and had to copy endlessly over the course of 400 hours from 7:00 to 11:00 PM every night! It's like teaching donkeys to carry bricks. And I said, 'Ah, so that's how it's going to be...' ...The students came from work smelly-oil rig workers, construction workers - and they came directly from work. There were 40 students in each class. The teacher went crazy one night. She told them, 'Copy, copy, copy' [what she had written on the board]. She wasn't teaching anything.

One day, there was a lot of chaos and confusion at the school. A student got on top of the teacher's desk and pooped, and he told her, 'Eat, eat, eat!' That was the teacher who always said, 'Copy, copy, copy.' It was an adult learner and he told her, 'Eat, eat, eat' after he pooped on her desk. I could not stand it. I quit. I ran out of there. Soon after that, I went to the Ministry of Education. At that time, I made the determination to start a literacy project for 40 hours. From 1983-1988, I trained 5 volunteer teachers to do a 40-hour literacy program. From a 400-hour literacy program, I reduced it down to 40 hours. Ten nights-four hours a night - for them to learn how to read and write.

Essentially, a key reason Soka education came to Brazil was as a result of a single woman's determined efforts to address educational, economic, and political injustices, which lead her to take action to create a solution beyond the official government-sanctioned ideas on how to solve 
issues of literacy. Her efforts also stemmed from her desire to respond to what she had learned from Daisaku Ikeda about Soka educational philosophy. As the only daughter and a descendant of Japanese immigrants to Brazil, Delia had come to learn about Makiguchi, Toda, and Ikeda from her parents. In all four interviews with Delia over a 3-year period, she shared how much she had to struggle and challenge resistance from many Brazilians who thought she was crazy and adamantly opposed to her efforts to start a Soka school in Brazil.

In addition to learning about the historical roots of Soka education in Brazil, this research focused on clarifying the quintessential qualities of selfidentified Soka educators. After coding the data and inductively identifying patterns shared by the interviewees (Maxwell, 2013) based on their narratives, it became clear that the self-identified Soka educators who were part of this research articulated and shared these qualities - as educators who are: reflective, selfless, mindful, compassionate/empathetic, seekers, and agentic. Each quality will be explained in more detail.

The quality of being reflective frequently emerged as educators shared about the process of becoming teachers who focused more on students' needs rather than their own. Educators opened up about experiencing cognitive dissonance (Cooper, 2007), which helped them recognize Soka educational philosophy as a sound philosophical educational alternative to the data- and assessment-driven approaches they had experiences and saw as dehumanizing for students. A key aspect articulated by educators centered on their reflecting on how their practices aligned with the educational ideas and posture towards students. For example, a teacher/administrator at the Brazil Soka School, Marcia, commented: "I guess I always think to myself: am I being true to what Daisaku Ikeda has been doing?" By studying and discussing key concepts about Soka educational philosophy together, the educators interviewed for this research shared how they often reflected on their own practices and ideas about education, with the goal of upholding this approach to education that centers on students and their life-long well-being.

The quality of being a selfless educator emerged, as the self-identified Soka educators often described the challenges this presents. One of the Soka Education in Action volunteers, Olivia, clearly articulated this point, when she shared:

When teachers change their attitudes, they are able to connect with the students because the teacher focuses on what the student needs. Because then it is not about their ego...what matters is how the teacher conveys it. This is what Makiguchi did. Treasuring the differences between each person. If there is someone that is very rational, they might get it faster. If the student is more artistic, then there are other ways to teach the student and the teacher has to adjust. 
The teacher has to reinvent another way to teach depending on the student. You can't force a student to learn something.

From this quote, which was echoed by other educators, selfless educators constantly challenge how to connect with students and support them to learn-persisting to creatively seek out ways to ensure that each and every student is able to learn and grow.

To be mindful as a Soka educator is linked to the notion voiced by the educators interviewed, who shared the importance of being mindful of each student's strengths, challenges, and unique life circumstances. The Soka educators interviewed shared the view that by being mindful of each student's distinctiveness, they developed the spirit to support each student in developing their potentialities and capabilities. For example, one of the teachers at the Brazil Soka School, Damario, who knew nothing about either Soka education, nor the school's founder, Ikeda, before he started working there, shared this: "You have the content, and you provide the student with that. Soka education goes beyond that; it changes destinies, stories, it's not only about imparting knowledge. It's to help students achieve their goals when they may not know that yet." This teacher quickly came to realize the power and profound value of Soka educational philosophy by encouraging teachers to be mindful of each student's unique potential-regardless of the content area. Damario taught high school science, demonstrating that Soka education is about teachers' underlying beliefs and philosophy, as well as attitudes and approaches in teaching - far beyond their academic disciplines.

The self-identified Brazilian Soka educators who were interviewed for this research shared that the qualities of being compassionate/empathetic are paramount. In the focus group with the volunteers in the Soka Education in Action, one of the educators shared this example, which illustrates this point that others also expressed in different ways:

A Soka educator has to show students the path and how to get there. This is to be benevolent. A Soka educator uses words and, in their attitudes, they need to have compassion, wisdom and benevolence. The essence that Makiguchi wrote about was that he washed students' cold hands and feet [on cold winter days]. He had the feeling for the students to be comfortable in his presence. Because when someone is comfortable, they aren't afraid to ask questions.

The self-identified Soka educators recognized an inextricable link between them showing students empathy and compassion, which is another way of describing "care" and students' capacities to learn and grow.

Another key finding that emerged from this research was the importance self-identified Soka educators placed on being seekers-regularly seeking to study and learn more about Soka educational philosophy. Both for the volunteer Soka educators in the Soka Education in Action project, as well 
as the Brazil Soka School teachers, the desire to study was palpable. A science teacher, Elisabete, who knew nothing about Soka educational philosophy before beginning to work at the school expressed her ideas this way: "I need to study more about Soka education and use my classroom also like a living laboratory - everyday asking myself, 'What's working? What isn't?' And again, to study more about Soka education." She looked forward to weekly book studies on the book by Ikeda (2010) entitled Soka Education.

Elena, another pioneer of Soka education in Brazil from the 1970s, continued to volunteer regularly in 2018 through Soka Education in Action even when she struggled to walk due to rheumatoid arthritis. She expressed her views on this topic this way:

So, the biggest challenge we face is to study together to create a consciousness about Soka educational philosophy. So many teachers already have these ideas about education, but we name them. It would be better if before a teacher starts teaching that they already have this kind of educational philosophy. Our biggest difficulty is this: when a teacher sees their actions based on this philosophy their consciousness shifts and there is a shift in their heart.

The self-identified Soka educators in this study acknowledged the importance of having a seeking spirit to study Makiguchi and Ikeda's ideas about Soka educational philosophy, in order to have a shift in consciousness and awareness about the very purpose of education and the significance of their roles as educators in the educative process.

The final quintessential attribute of a Soka educator that emerged in the course of conducting this research is the quality of being agentic. For the self-identified Soka educators, being agentic included the notion of being protagonists in their teaching, as well as fostering students to be the protagonists in their learning - with the focus being on taking action to create a more just world. Consistently - based on observations, interviews and informal dialogues - the Soka educators and students shared the idea that their working at or attending a Soka school, or volunteering at a public school and sharing ideas that illustrated concepts about Soka educational philosophy, they were serving as agents of change on both the local and global scalethrough education.

In an interview with a PE teacher, Martin, who shared his struggles to understand how Soka educators are in any way different from other educators, came to this realization, which encapsulates the idea of Soka educators being "agentic:"

We see the Founder [Ikeda, the school's founder] as a humanist, a pacifist. To create a school system that transmits these important values will provide another way to support a social change in society - independent of religion. I think that 
for us to develop young people with humanistic values who know that they have great potential and that those youth around them also have great unlimited potential - to up this into action and create social change...independent of any religion-will create a significant movement for Brazil and the world.

This sentiment was echoed in many talks with students and teachers in the course of seeking to make meaning and understand some of the essential qualities or attributes of Soka educators. The view of connecting the work done in education to greater societal change based on individual agency and linked to the agency of others, is a unique and distinguishing aspect of Soka educators.

\section{Additional Findings}

Liminal spaces. Another important finding of this research is that learning about Soka educational philosophy for students and teachers often occurred in liminal spaces, also called "third spaces" (Bhabha, 1994), such as at sports festivals, a book club, or in library exhibits, which showed that consistently studying and sharing Ikeda's writings about Soka educational philosophy is critical in order to maintain fidelity to the founding principles. This became very clear through meeting with several of the original volunteer educators from the Makiguchi Project in Action, now called "Soka Education in Action." Delia studied the teachings and writings of Makiguchi and Ikeda for five years with a small group of mostly women before modifying the original 400-hour government literacy program to a 40-hour one. Delia continued to seek from Ikeda and study Makiguchi's writings until the Brazil Soka School officially opened in 2001-after receiving permission from the Soka Gakuen, the name of the official administrative arm of Soka schools, housed in Tokyo. She is now in her mid-80s, but she shared that she visited Japan 32 times - always with the spirit to seek and learn from Ikeda and Soka educators in Japan about how to put Soka educational philosophy into action in Brazil.

Other examples highlight how important regular study is in order to put the ideas of Soka educational philosophy into action. During the 2018 school year, teachers at the Brazil Soka School studied Ikeda's book Soka Education every Friday, and different teachers took responsibility to do a chapter review. Elisabete, a physics teacher who never known about Soka education before starting at the school, shared her story as her eyes filled with tears when she described sharing the last chapter:

I told them that I was very confused still, but I know this is something very important. Because I know Soka education is not something separate from our reality - that it is something we live and that I'm still learning to be a Soka 
educator. Today, I have the consciousness that I no longer

feel anxious at all about this-thinking this is precisely what

it is. Here, our school is our laboratory; here is where we

learn about Soka education, and we learn when we are in our

classrooms with our students. We learn day by day.

Something that is very important to me is this: who is

teaching me the most? My students.

This teacher came to precisely the same conclusion as Dewey and Makiguchi: schools and classrooms are very much living laboratories where educators constantly engage in questioning, researching, trying out new ideas, and learning through the process. Several other staff members shared how moved they were when Elisabete shared her realization at the book study, and this is particularly cogent because she was learning about Soka education as she sought to apply the ideas and principles in her daily work as a teacher.

Through Brazil's Educational Coordinating Group, called the Coordenadoria Educaccional, the umbrella organization overseeing the Soka Education in Action group, one of the volunteer educators shared that a group of women who support their work have been systematically going through each of Ikeda's 30 volumes about his life's work, called The New Human Revolution, in order to focus specifically on what Ikeda says about education, Soka education, and humanistic education. This is yet another example of the role study plays, along with the value of a seeking spirit to understand Ikeda's views about Soka educational philosophy. In this way, self-identified Soka educators can hope to apply the ideas of Soka educational philosophy in a manner that aligns with the original ideas of Makiguchi, along with the current ways Soka education is expressed through Ikeda's vision and writings.

The Role of "Care" in Soka Education. Again, a distinguishing aspect of Soka education is the emphasis on linking education to students' lifelong happiness, which can be directly linked to the qualities of being compassionate/empathetic. Historically, learning was based on personal relationships between the student and the teacher. Noddings and Shore (1984) note that teachers and their students lived together and developed extensive personal relationships, with teachers caring for the intellectual and personal growth and development of students as far back as the Middle Ages. Today, care in education represents a complex phenomenon for several reasons: a) some do not see teaching as a caring profession because the teachers' goal must be delivering adequate academic achievement and the cultivation of global competence among students (Narinasamy \& Mamat, 2013; Noddings, 2007; Wilde, 2013), making care an accessory to the real work of teaching (Wilde, 2013); b) there is no clear, collective construction of what it means to care and how teachers can create and maintain caring relationships with students (Adler, 2002); c) teachers and students have differing perceptions of 
what care looks like, and that difference is affected by several variables, including age, ethnicity, gender, cultural mismatch of the teacher and student(s), and other demographic factors (Hayes, Ryan, \& Zseller, 1994). Despite the perplexity of care in the context of teaching and learning, whether-or-not students thrive in their learning environment is often predicated on the relationship between the student and the teacher, and whether-or-not the student believes the teacher cares about the student as an individual - a unique and valued human being.

Unfortunately, learning how to care for students has not been wellarticulated in most teacher education programs (Knight, 2004). This leaves teachers struggling to figure out how to effectively and appropriately demonstrate caring behaviors that leave students feeling valued and authentically cared for. This struggle is exacerbated as pre-service teachers gain classroom experience under an education system that has become so focused on rigid curriculum and high-stakes testing that the endless list of things to do overshadows the practice of care (Cooper, 2004). Over time, these teachers become veteran educators juggling large class sizes, short periods, curriculum demands, and their own isolation, which contributes to the "emotional vacancy of schools" (Hayes, Ryan, \& Zseller, 1994, p. 2). Consequently, as teachers live their personal teaching philosophy, even if the early written version describes a desire to care for students and outlines behaviors and practices that might demonstrate that care, the reality most often reveals care as ancillary at best.

In terms of Soka educational philosophy, Makiguchi was clear about the role of teachers to care genuinely about their students. Makiguchi (1936/2015) wrote that ideas about "if teachers fully embodied the spirit of one who is a servant of chrysanthemums, determined to bring beautiful flowers to bloom, education would succeed without fail" (p. 245). For Makiguchi, the essence of his views on education is distilled in this powerful image - of teachers who carefully and attentively serve as loving gardeners who patiently care for each flower, confident that each one will bloom-based on teachers' compassion.

Examples of care in action at the Brazil Soka School were plentiful in the course of this research. Part of this was because a common feature of all Soka schools is connected to meals - how they're prepared, served, and eaten. All meals were prepared by kitchen staff, who consider themselves Soka educators - along with the porters at the entry and the cleaning staff. For each meal, fresh fruits and vegetables were served, and the open dining room concept meant that all staff and all students ate together. Meals, then, became a way for all of the staff to interact with each other and with students - so that showing care through sharing meals became part of the fabric of everyone's life on a regular basis. 
Another component of caring was clear when teachers shared their attitudes towards students who might be failing. Consistently, teachers shared that it was unacceptable that a student "wouldn't get it." Rather, the onus was on the teacher to persist in finding innovative and creative ways to connect with each student and support them until they understand and master the skill or subject. This point was made often: teachers show care by persisting in their spirit to support and care for each and every student.

\section{Linking Critical Thinking in an IB School with Soka Educational} Philosophy. The Brazil Soka School has developed two international partnerships that support their efforts to foster students to become criticalthinking global citizens. One such collaboration is with the UNESCO Associated Schools Network, and the other one is with the International Baccalaureate Programme. The challenge for the Brazil Soka School is integrating these various program goals, while also maintaining a Soka educational foundation and spirit. A clear example was shared by a teacher whose pseudonym is "Antonio;" he highlights how he brought together the confluence of ideas of Soka educational philosophy with critical thinking.

During the 2018 school year, the country of Brazil hosted an International Forum on Water. Antonio, an IB social studies teacher, created a lesson where the students signed up and learned about the countries that participated and researched water issues in those countries. They created a "mini world water forum," and each student explained water scarcity issues in the country they researched. Also, the school held a cultural show, and as part of that project, they learned about the history of Soka education. As parents and guests entered the classroom, they were greeted by a student dressed as Makiguchi, who invited everyone to enter and learn about current environmental issues. This activity linked students' academic studies to local and global issues, which is a Soka educational idea.

Antonio explained the lesson in this way:

On the floor, the students created a crime scene-like an outline of a person on the floor of a crime scene and the students wrote stories in little squares-about Chernobyl and Fukushima-about disasters that have happened in our world that show this kind of lack of harmony between human beings and nature. And when talking about the future, they talked about themselves and their roles as Soka students with regards to all these challenges. It was like in a laboratory that has an instrument that teaches about waves-a wave machine. You hit this apparatus and create a wave and then it goes back. So, the students explained that such a relationship that they had with Makiguchi was as if 


\section{Makiguchi hit that apparatus and started the wave and that}

wave went out into the world and returned to their lives.

The activity allowed students to learn about an important Soka educational principle - about their roles as students to take action in the world - while also exposing them to serious international environmental crises. Through this example, we see how a self-identified Soka educator creatively brought together central ideas about Soka educational philosophy together with a lesson that also links to both the UNESCO and IB partnerships that all support students to develop and strengthen critical thinking skills while fostering students to become global citizens.

\section{DISCUSSION AND CONCLUSIONS}

This research on Brazilian self-identified Soka educators provides rich examples of pioneers in the field of contemporary PK- $12^{\text {th }}$ grade Soka education in action. The attributes of self-identified Soka educators gleaned from this research include the following qualities: reflective, selfless, mindful, compassionate/empathetic, seekers, and agentic. Recognizing and naming these attributes is essential to further expand ideas about Soka educational philosophy and what it means to be a Soka educator. Brazil is a vast countrylarger than the continental United States - and the efforts of the educators at the Brazil Soka School and volunteers in the Soka Education in Action professional development program might seem minuscule in the large scheme of educational efforts worldwide. However, we might see this from a different view based on an address Ikeda gave to students from the Kansai Soka Junior and Senior High Schools in Japan in 1973 - at their first entrance ceremony. At that time, Ikeda said, "in comparison with the wide world, the Soka schools may be as small as a poppy seed, but if our students remain true to this ideal [of the school's principles]...our impact will be felt all over the globe" (Unger \& Ikeda, 2016, p. 87). Through these words, we sense Ikeda's conviction in the important role of Soka education and the unquestionable impact of Soka educators and students.

Pereira (2008) shares that "Ikeda himself has always reinforced the idea of Brazil as the fountain, the pioneer, the model, the 'monarch'... and the farthest country from Japan but the closest to his heart" (p. 108). This point is extremely important: based on this research conducted in Brazil, those who seek to apply and spread ideas of Soka educational philosophy will benefit by strengthening their commitment to align with Ikeda's spirit and heart about education. Whether one is an educator who works at a Soka school sanctioned by the Soka Gakuen (the administrative offices over officially-sanctioned Soka schools), such as the Brazil Soka School, or in the field of education on any level, this research found that it is essential that self-identified Soka educators study and seek to understand how to apply Ikeda's views on education, along with his insights on the importance of deeply caring for 
students - showing compassion and empathy. This includes a spirit to work tirelessly to develop classrooms and schools where each child will be nurtured and cared for so that all children who experience Soka educational philosophy in action develop their greatest potential and are able to experience a long life of fulfillment and happiness while working to make the world a better place for all.

The research presented in this paper on Soka educational philosophy as it is being applied in Brazil is just the tip of the iceberg. As this educational philosophy that originated in Japan is taking root in PK-12th grade settings throughout Brazil, suggestions for future research include: a) an in-depth look into a pilot public school in São Paulo that is based on principles of Soka educational philosophy, comparing it to similar public schools in the areaspecifically around areas of the school's culture and climate, along with issues of discipline; b) a broader and more in-depth study on the various "Soka Education in Action" projects throughout Brazil, since this research focused on the São Paulo region; c) the role of Brazilians of Japanese descent in applying Soka educational philosophy in Brazil; and d) comparing the success of the Brazil Soka School with similar private schools in Brazil, in terms of looking at a wide range of elements that contribute to markers of a school's success in Brazil.

In informal interviews, it became clear that many self-identified Soka educators started small private schools, such as a language school, a tutoring school, and a small high-tech high school. In the absence of any formal guidelines about what constitutes a "Soka" educator, research on how and why these educators consider themselves to be Soka educators warrants further research. Brazil is unique in that so many educators are taking the initiative to apply ideas they have studied about Soka education, and systematic research on the success of their endeavors could shed light on how future educators can incorporate such ideas about Soka education in various realms.

\section{IMPLICATIONS}

Brazil is the only Western country with a PK- $12^{\text {th }}$ grade school imbued with Soka educational philosophy, while also functioning under required national curricular guidelines. This is significant because the Brazil Soka School serves as an exemplar for educators worldwide to see that such an approach to education is possible - regardless of the local conditions. This means that while functioning under strict educational criteria established by the federal government, the educators at the Brazil Soka School were simultaneously able to create a school ecology based on care, with the end goal being students' lifelong happiness linked to creating a more just world for all humankind. 
At the same time that the Brazil Soka School is developing its foundation, a robust network of volunteers who have informally, but systematically, studied Soka education for decades are also broadly spreading the ideas of Soka educational philosophy with public school educators throughout Brazil. The Soka Education in Action network of volunteers is functioning throughout the country of Brazil, and for precisely this reason, the research conducted on both the Brazil Soka School and Soka Education in Action is pertinent and essential as a record of how this educational philosophy is put into action at the grassroots level.

\section{REFERENCES}

Alder, N. (2002, March). Interpretations of the meaning of care: Creating caring relationships in urban Middle school classrooms. Urban Education, 37(2), 241-266

https://doi-org.srv proxy2.library.tamu.edu/10.1177/0042085902372005

Bhabha, H. (1994). The location of culture. Routledge.

Breinholt, A. \& Jæger, M. How does cultural capital affect educational performance: Signals or skills?

British Journal of Sociology 71(1), 28-46. doi: 10.1111/1468-4446.12711

Clandinin, D. J. (2015). From teacher thinking to teachers and teaching: The evolution of a research community. In C. J. Craig, P. C.

Meijer, \& J. Broeckmans (Eds.). Advances in research on teaching (pp. 6795). Emerald Group Publishing.

Clandinin, D. J., \& Connelly, F. M. (1992). Teacher as curriculum maker. In P. W. Jackson (Ed). Handbook of research on curriculum (pp. 363-461). Macmillan.

Connelly, F. M., \& Clandinin, D. J. (1990). Stories of experience and narrative inquiry. Educational Researcher, 19(5), 2-14.

https://doi-org.srproxy2.library.tamu.edu/10.3102/0013189X019005002

Cooper, B. (2004, September). Empathy, interaction and caring: Teachers' roles in a constrainedenvironment. Pastoral Care, 12-21.

doi: 10.1111/j.0264-3944.2004.00299

Cooper, J. (2007). Cognitive dissonance: Fifty years of a classic theory. Sage.

Craig, C. J. (2013). Teacher education and the best-loved self. Asia Pacific Journal of Education, 33(3), 261-272, https://doi.org/

$10.1080 / 02188791.2013 .788476$

Craig, C. J., \& Ross, V. (2008). Cultivating the image of teachers as curriculum makers. In F. M. Connelly (Ed.), Sage handbook of curriculum and instruction (pp. 282-305). Sage.

Dewey, J. (1897). My pedagogic creed. The School Journal, LIV (3), 77-80.

Eisner, E. (1988). The primacy of experience and the politics of method. Educational Researcher 17(5), 15-20.

Garrison, J., Hickman, L., \& Ikeda, D. (2014). Living as learning: John Dewey in the $21^{\text {st }}$ century. Dialogue Path Press. 
Goulah, J. (2010). From (harmonious) community life to (creative) coexistence: Considering Daisaku Ikeda's educational philosophy

in the Parker, Dewey, Makiguchi, and Ikeda "reunion." Schools: Studies in Education, 7(2), 253-275.

https://www-jstor-org.srv-proxy2.library.tamu.edu/stable/10.1086/656075

Goulah, J., \& Gebert, A. (2009). Tsunesaburo Makiguchi: Introduction to the man, his ideas, and the special issue. Educational

Studies, 45(2), 115-132. doi: 10.1080/00131940902762144.

Goulah, J., \& Urbain, O. (2013). Daisaku Ikeda's philosophy of peace, education proposals, and Soka education: Convergences

and divergences in peace education. Journal of Peace Education, 10(3), 303322. doi: $10.1080 / 17400201.2013 .848072$

Guajardo, M., \& Reiser, M. (2016). Humanism as the foundation for global citizenship education. Journal of Research in Curriculum \& Instruction, 20(3), 241-252.

Hayes, C. B., Ryan, A., \& Zseller, E. B. (1994, November). The middle school child's perceptions of caring teachers. American Journal of Education, 103(1), 1-19. https://doi.org/10.1086/444087

Ikeda. D. (2001). Soka education: A Buddhist vision for teachers, students, and parents. Middleway Press.

Ikeda, D. (2006). To the youthful pioneers of Soka: Lectures, essays and poems on value-creating education. Soka University

Student Union.

Ikeda, D. (2009). Foreword. Educational Studies: A Journal of the American Educational Studies Association, 45(2), 111-114. doi: 10.1080/00131940902762128.

Ikeda, D. (2010). Soka education: For the happiness of the individual. Middleway Press.

Knight, M. G. (2004, September). Sensing the urgency: Envisioning a black humanist vision of care in teacher education. Race,
Ethnicity
and
Education,
$7(3)$
211-225. https://doi.org/10.1080/1361332042000257047

Makiguchi, T. (2015). On attitudes toward education: The attitude toward guiding learning and the attitude toward learning. Schools:

Studies in Education, 12(2), 244-251. (Original work published 1936)

Maxwell, J. A. (2013). Qualitative research design: An interactive approach ( $3^{\text {rd }} \mathrm{ed}$.). Sage.

Nagashima, J. T. (2012). Daisaku Ikeda's philosophy of Soka education in practice: A narrative analysis of culturally specific

language. Critical Inquiry in Language Studies, 9(1-2), 132-151. https://doi.org/10.1080/15427587.2012.648072

Narinasamy, I., \& Mamat, W. H. (2013, December 26). Caring teacher in developing empathy in moral education. The Malaysian

Online Journal of Educational Science, 1(1), 1-19.

Noddings, N. (2007). Teaching themes of care. In B. Lerner, \& L. K. Terry, Character (Vol. 14, pp. 1-5). Association for Supervision 
and Curriculum Development Character Education Network and Center for the Advancement of Ethics and Character at the

School of Education at Boston University.

Noddings, N., \& Shore, P. (1984). Awakening the inner eye: Intuition in education. Teacher College Press

Olson, M. R., \& Craig, C. J. (2001). Opportunities and challenges in the development of teachers' knowledge: The development of

narrative authority through knowledge communities. Teaching and Teacher Education, 17, 667-684. doi:

10.1016/S0742-051X(01)00023-3

Pereira, R. A. (2008). The transplantation of Soka Gakkai to Brazil: Building "the closest organization to the heart of

Ikeda-Sensei." Japanese Journal of Religious Studies, 35(1), 95-113. http://www.jstor.org/stable/30234503

Schwab, J. T. (1954). Eros and education: A discussion of one aspect of discussion. The Journal of General Education, 8(1), 51-71.

Sharma, N. (2011). Revisiting the concept of dialogue in global citizenship education. International Journal of Development

Education and Global Learning, 3(2), 5-19.

Sherman, P. D. (2016). Value creating education and the Capability Approach: A comparative analysis of Soka education's

facility to promote well-being and social justice. Cogent Education, 87(1), 1-15. https://doi.org/10.1080/2331186X.2016.1138575

Silva, D. (2000). Makiguchi in action: Enhancing education for peace. The Journal of Oriental Studies, 10, 62-93.

Soka Gakuen Educational Foundation. (2009). Soka gakuen: A system for cultivating human values. Author.

Unger, F., \& Ikeda, D. (2016). The humanist principle: On compassion and tolerance. I. B. Tauris Co. \& Ltd.

Wilde, S. (2013). Care in education: Teaching with understanding and compassion. Taylor \& Francis.

Vicki G Mokuria, Ph. D. is a Visiting Assistant Professor in Education Studies at Stephen F. Austin State University. Her major research interests lie in the areas of teacher education, anti-racism education, Soka education, and multiculturalism. Email: vgmokuria@gmail.com.

Diana Wandix-White, Ph.D., is a Clinical Assistant Professor at Texas A\&M University - San Antonio, College of Education and Human Development. Her research foci are teacher education, culturally relevant teaching materials, and intercultural communication at the intersection of educational equity. 